\title{
SPECIES DISTRBUTION WITHIN RIPARIAN LANDCAPE ALONG MAYO KAM OF GASHAKA TARABA STATE, NIGERIA \\ Mubi, A. M.
}

DOI: http://dx.doi.org/10.4314/ejesm.v5i1.6

Received $30^{\text {th }}$ December 2011: accepted $7^{\text {th }}$ Febrary 2012

\begin{abstract}
The study examines species density and diversity distribution in riparian landscape along $18 \mathrm{~km}$ stretch of Mayo Kam. Total of 117 Samples quadrants of $125 \mathrm{~m}^{2}$ (46), $225 \mathrm{~m}^{2}$ (25), and $275 \mathrm{~m}^{2}$ (46) from strata $5 \mathrm{~m}$ (zone A), $9 \mathrm{~m}$ (zone B), and $11 \mathrm{~m}$ (zone C) respectively away from the Channel Bank Edge (CBA) through the Hydraulic Floodplain (HFP) and the Genetic Floodplain (GFP) were delineated and detailed survey was carried out. Data was collected on river bank morphology, altitude a.m.s.l., slope gradient, soil type, and tree species density and diversity. Result of species distribution revealed mean densities and diversities in zones $A, B$, and $C$ as, 10 and 4 per $125 \mathrm{~m}^{2}, 10$ and 3 per $225 \mathrm{~m}^{2}$, and 23 and 5 per $275 \mathrm{~m}^{2}$ respectively. Accordingly, density and diversity per $625 \mathrm{~m}^{2}$ show maximum of 83 and 8 and minimum of 5 and 5 on outer convex bank and inner straight bank. Brachystigia eurycoma, Vetix doniana, Andria enermis and Diospyrus spp are the obligates of zone A. Characterizing zone B are Anogeisus leocarpus, Peninari excelsa, Crossoptyx februfuga and Nauclea latifolia species while, common species in zone C are Uapaka togoensis, Terminalia glaucoscens, and Grewia mollis. The dense and diverse pattern in the distribution within the three zones is importantly due to relative location of stratum from channel flow (variation in moisture availability), morohologic form, soil type and slope gradient.
\end{abstract}

Key Words: Bank form, density, diversity, landscape, Mayo Kam, riparian, species

\section{Introduction}

The riparian landscape are among the most diverse and productive habitats and perform several critical ecological functions. An infinite variety of plants e.g. herbs, grasses, trees etc. are found to thrive along the riparian landscape and the rivers. The geomorphic heterogeneity of patches on floodplain in terms of their size and age are critical component of a healthy river ecosystem; and that a patchwork of geomorphic unit nested at spatial scale can provide special habitats requirements (Gurnel, 1997, Florian, et al., 2004;) and high biodiversity and biological activity (Paul et al., 2010). For most of the plants, running fresh water is the only habitat in which they can survive. For others it is one of the ranges of habitats where they can be found. Variation in water depth, flow velocity and associated bed floor material, bank morphology and slope, soil type among others are some of the factors that form an intricate pattern of zones which types of plants may inhabit (Bendix and Hupp, 2000; Collins and Battaglia, 2001; Webb and Erskine, 2003). The

Department of Geography Modibbo Adama University of Technology P. M. B. 2076, Yola Adamawa State, Nigeria Email:ammubi@yahoo.com sharpness of ectone between plant communities and individual landform is related to the degree to which landforms are linked through the flow of water and sediment (Steven et al., 1996). The significance of river channels and their adjoining riparian forests in nature-protected area has well been recognized. This is because the riparian areas, though narrow, distribute water, has high diversity and productivity, and connects all other habitat types from highest to the lowest elevation and act as a functional net in supporting landscape diversity (Baker and Wiley, 2004; Jiang et al., 2005; Blake et al., 2009; Paul et al., 2010; Mao et al., 2011). Several plant and animal species are obligate to this system. Current strategy for restoring aquatic habitat, water quality, and riparian ecosystem services is the protection of fluvial geomorphic-based river corridors and associated floodplain attributes and functions (Warren, 2001; Thomson,2001; Florian et al., 2004; Mubi; 2008; Paul et al., 2010). Thus, the study of the plant types, density, diversity and distribution pattern and the geomorphic (landscape) factors that influenced them along Mayo (river) Kam channel. 


\section{Study Area}

The surveyed riparian landscape is $18 \mathrm{~km}$ reach along a sand-gravel bed channel of Mayo (river) Kam in a nature protected area of GashakaGumti National Park (GGNP) in Taraba state, Nigeria. With a basin area of $2,232 \mathrm{~km}^{2}$ the river is located within Latitude $7^{\circ} 14^{\prime}$ and $7^{\circ} 26^{\prime}$ North of the Equator and longitude $11^{\circ} 17$ ' and $11^{\circ} 20^{\prime}$ East of the Greenwich meridian. The drainage basin of Mayo Kam lies in the wet southern sector of the Park and receives over $2000 \mathrm{~mm}$ mean annual rainfall spread over eight months-March to October. Mean minimum and maximum temperatures ranges between $22^{\circ} \mathrm{C}$ and $31^{\circ} \mathrm{C}$ with the coldest and hottest days temperature records of $20^{\circ} \mathrm{C}$ and $34^{\circ} \mathrm{C}$ respectively.

\section{Methodology}

A reach $18 \mathrm{~km}$ along Mayo (river) Kam the major river in GGNP was sampled and detailed species distribution within the river geomorphic forms and nearness to channel flow investigated. With a mean gradient of $1.5^{\circ}$ within the middle section studied, the channel featured matured and old age non braiding characteristics of a channel plan form. Sampled units for investigation were delineated in the field based on the morphology of the river channel banks: inner/outer concave, inner/outer convex and inner/outer straight banks. This was based on the understanding that, bank slope materials and their variability are inseparately linked to channel form and, bank form in particular influences erosion and deposition processes. Features like meander is of key importance to flora and fauna communities, it exhibit varied and diverse channel habitats such as eroding banks and/or bank pool, riffle, turbulent and still water, sheltered and exposed sites. The varied and unique characteristics make such high structured diversity rich in biodiversity in and along the channel. Sample quadrants $125 \mathrm{~m}^{2}$, $225 \mathrm{~m}^{2}$ and $275 \mathrm{~m}^{2}$ at $5 \mathrm{~m}, 9 \mathrm{~m}$ and $11 \mathrm{~m}$ respectively away from the river banks were delineated along the sampled reach from the Channel Bank Edge (CBE) through Hydraulic Floodplain (HFP) and the Genetic Floodplain (GFP). Along and within this range the vegetation displayed three distinct zones thus; data was collected on bank morphology, altitude, slope gradient, soil type, vegetation density and diversity.

\section{Results and Discussion}

Three distinct zones of vegetation types were identified along the reach. Zone $\mathrm{A}$, the riparian forest was mapped from and within 5 meters away from the channel banks edge and is composed of trees, shrub, tangle and climbing plants. Some of the tree species in this zone include the most conspicuous because of its height and red bright flowers Brachystigia eurycoma, others are Vitex doniana, Andria enermis, and Diospyros spp. Shrubs, tangle and climbing vegetation add up to the thickness of vegetation in this zone. The riparian zone gives way to the out ward adjoining relatively large zone $\mathrm{B}$ which is 9 meter wide on average. The zone is dominated by grass and few isolated tree stands. The most occurring tree species in this zone are Anogeissus leocarpus, Perinari excelsa, Crossopteryx februfuga and Nauclea latifolia. The 11 meter wide outermost zone $\mathrm{C}$ is covered by woodland and grass; trees constituted the larger proportion of the cover type. Uapaka togoensis, Terminalia glaucoscens, Grewia mollis are some of the common species in zone C.

Examination of species distribution in the 117 investigated quadrants of the three zones shows variation in both density and diversity numbers. Minimum species density of 5 , and diversity of 5 per $625 \mathrm{~m}^{2}$ at sampled unit on the outer straight bank, and maximum species density of 83 and diversity of 8 per $625 \mathrm{~m}^{2}$ for the diversity are recorded at sampled unit on the outer convex bank of the channel while, mean values are density 42 and diversity 12. Accordingly, the means densities and diversities for zones A, B and C are 10 and 4 per $125 \mathrm{~m}^{2} 10$ and 3 per $225 \mathrm{~m}^{2}$ and 23 and 5 per $275 \mathrm{~m}^{2}$ (Table 1). Zone A which has an average width of 5 meters represent the valley floor area adjacent to the river channel. The section constitutes the genetic flood plain which is largely horizontally bedded and composed of alluvium deposits adjacent to the channel. The section is present throughout the surveyed reach. The location of zone A therefore makes it to have high moisture availability throughout the year, hence the riparian forest in the zone. The high species density 10 and diversity of 4 per $125 \mathrm{~m}^{2}$ in the zone could also not be un-connected with the nearness of this zone to the river channel. Soils on the banks within 5 meters from the channel comprised largely of silt loam and sandy loam soils, 
conditions for the cover type. The high content of litter fall adds up to the quality of soil in the zone.

Zone B consist of silt loam to clay loam soil soils and support relatively low density of 10 and diversity of 3 per $225 \mathrm{~m}^{2}$. This could be attributed to the fact that zone B is lying some distance that is within 5 to 14 meters away from the main channel/its genetic flood plain. This makes it moisture deficit for riparian plants which inhabit zone $\mathrm{A}$ and is relatively wetter to favor plant species of zone C. Zone B is characterized by silt loam and clay loam soils and its location can best be described as the hydraulic flood plain (to be distinguished from the genetic flood plain) which is inundated at least once during a given return period of a river flood activity. Thus, the low species density and diversity in zone B in partly caused by the periodic hydro-dynamics of the soil, which makes moisture not sufficiently available all year round for the riparian vegetation, particularly for species like Brachystigia eurycoma, Diospyros spp, and Andria enemies the distinctive and specialist tree species in zone A to thrive in the zone. While plant species such as Uapaka togoensis, Psedocidria kochyell, Vitelaria paradoxum of the well drained elevated zone $\mathrm{C}$ also found zone B not favorable for their habitation. Nonetheless, annual grasses and few widely dispersed trees for example, Terminalia glacoscens, Crossptaryx februfuga, and Parinari excelsa are the obligaes plants in this moisture transient zone B. Furthermore, low species density and diversity in zone $\mathrm{B}$ can also be linked to the conservation method practiced by the Park Management. The prescribed annual burning technique to quicken the sprout of new grasses/succulent and nutritious plants for animals to feed on has additionally affected plant species in zone B. When set on fire the grasses and some of the few trees in the zone get burnt completely (see Plate 2a and b), rendering the soil bare of surface cover and/or concentration of tree stands. Therefore, species types, low density and diversity in zone $B$ are the result of the interactive effects of the hydro- dynamics and annual burning. As such, only plants that can withstand the dynamic conditions of the zone thrive there. Low density of species in zone B could further be attributed to the contributing effect of the apparent trail of animals along the path, because of the adjacent location of zone B to zone A (close to water channel) and the absence of tangle vegetation that assures ease of movement.

On the gravel-sand and sandy loam soils of the $11 \mathrm{~m}$ wide outermost zone $\mathrm{C}$, large proportion of trees and scattered grasses constituted the cover types. Uapaka togoensis, Terminalia glaucoscens, Grewia mollis are some of the common species in this zone. Species like Brachystisia encrycoma are specialist to their environment, found only on the bank forms of the river in zone A. While, species such as Upaka togoensis, and Anonna senegalensis are generalist of zone B and C.

In the study area species types and their distribution vary with distance from the river channel in the same way soil types, elevation and slope gradient vary with relative location to the river channel. With distance from the channel soil type and moisture, slope gradient all varied so also change in species type, density and diversity (Table 1). This pattern is in agreement with findings, Wittmann et al. (2004) species distribution and diversity varied on the flood-level gradient with distinction between low-várzea forests and high várzea forests; and Florian et al., (2006) species richness and distribution along gradient of flooding and sedimentation was well defined in White-water forest Amazon Basin. That, only $2.6 \%$ of the 222 recorded tree species occurred over the whole flood-level gradient in a total area of 5.24 ha surveyed.

Investigation of species distribution within bank morphologic forms showed control of bank morphology on density and diversity concentration per unit area. The outer/inner concave and the inner/outer convex banks of the river channel have attracted high species densities. Values obtained are 50 and 46 per $625 \mathrm{~m}^{2}$ species densities in the outer/inner concave banks and related diversities of 11 and 11. Similarly, the outer/inner convex banks have also higher densities of 47 and 38 with associated diversity of 15 and 13 per $625 \mathrm{~m}^{2}$. Conversely, the outer/inner straight banks supported low 32 and 33 species densities and related high species diversities of 12 and 12 per $625 \mathrm{~m}^{2}$ (Table 2). This is similar to the species distribution pattern observed, species distribution dependent on specific fluvial landforms and processes which has been identified in natural (undisturbed) river system (Bandix and Hupp, 2000; Florian, et al., 2004; Renöfält et al., 2005; Hiroka et al., 2006, Robertson, 2006, and Paul et 
al., 2010). Furthermore, this study found out that, composition of diverse species is independent of species density and banks morphology. This is because the low species densities in the inner/outer straight banks are found to be equally supporting high diversities as those obtained in the concave and convex banks units. The concentration or high diversities per unit area $\left(625 \mathrm{~m}^{2}\right)$ are therefore not functionally related to morphology of the river bank forms.

The species high densities association with the concave and convex banks is undoubtedly due to the fact that these forms of the river section are of unique characteristics in the river activity. The convex river bank meander, for example, is of key importance to flora and fauna conservation for it exhibit all variations in channel habitat- eroding banks (and or cliff), pool, riffle, turbulent and still water. These varied and unique characteristics make such sites rich along the riparian corridor. The concave banks on the other hand are geomorphologically zones of sediment deposits and by extension; are rich in nutrients composition. The high densities recorded in the concave/convex banks morphologic units could therefore be attributed to the banks' forms characteristics and the varied hydraulic activities. Trees falling from the banks into the inner side of the channel banks have also influenced the composition and richness or diversity of vegetation on the banks (see Plate 3). Significance of such vegetation in river ecology has been in the distribution and recruitment of geomorphic habitats (Webb and Erskine, 2003). Such fallen trees from the banks have the ability to trap river transported load that help create diverse habitats which different types of plant species colonized. The inner/outer straight banks, because of their linear nature partly increase river activity and sediment transport with short time lag unlike the characteristics of turbulent mixing of the water and/or its still form in the convex bank that encourage sediment deposition on such banks. The result is less sediment deposits on the banks and few habitat types with accompanying low density as observed in the straight banks sampled in the studied reach.

\section{Conclusion}

The paper established that, species distribution pattern within riparian landscape of Mayo Kam exhibit both longitudinal and horizontal variation as well as it is significantly influenced by the morphology (shape) of channel banks. This is particularly revealing on the outer convex, concave and straight river banks as densities significantly varied between these geomorphic units. Conversely, there is no association in the distribution of diverse species with either bank morphology or species density since findings indicated that the variously varied bank forms all have relatively equal number of diverse species. Relative location of riparian landscape to channel flow, soil types, and bank morphology and elevation above water level are factors observed to be significant in the distribution of diverse species and densities.

\section{References}

Bandix, J. and Hupp, C.R. (2000), Hydrological and geomorphological impacts on riparian plant communities. Geomorphology,14(16-17), 2972990.

Baker, M. E. and Wiley, M. J. (2004), Characterization of woody species distribution in riparian forest of lower Michigan, USA using map-based models. Journal: Wetlands, 24(3), 550 -561 .

Blake M. E., Jeanne C. C., and Peter J. W. (2009), Influence of geomorphology on the distribution and sensitivity of great basin riparian plant communities: A multi-scale analysis. $94^{\text {th }}$ ESA annual meeting. Albuquerque Convention CenterAlbuquerque, New Mixico.

Collins, B.S. and Battaglia, I. L (2001), Hydrology effects on propagate bank expression and vegetation in six Carolina Bays Community Ecology, 2, 21-33.

Hiroka, I., Satoshi, I., Tamotsu, M., and Tomomi, M. (2006), Effects of fluvial geomorphic disturbance on habitat segregation of tree species in a sedimentation dominated riparian forest in warm temperate mountainous region in southern Japan. Journal of Forest Research, 11(6), 405417.

Florian, M., Wolfgang, J. J., and Maria, T. F. P. (2004), The Varzea forests in Amazonia: flooding and the highly dynamic geomorphology interact 
with natural forest succession. Forest Ecology and Management, 196(2-3), 199-212.

Florian, W., Jochen, S., Juen C. M., Thomas, M., Wolffng, J. J., Maria, T. F. R., Helder, L. Q., and Martin, W. (2006), Tree species composition and diversity gradients in White-water forest across the Amazon Bazin Journal of Biogeography. Blackwell Publishing Ltd.

Gurnel, A. (1997), The hydrological and geomorphological significance of forested floodplains. Global Ecology and Biogeography Letter 6(314), 19-229.

Jiang, M., Deng, H., Cai, Q. and Wu, G. (2005), Species richness in a riparian community along the banks of the Xiangxi River, the Three Gorges region. International Journal of Sustainable Development and World Ecology, 12(1), 60-67.

Mao, L., Vitti, p., Picco, L., Comiti, F., Sitzia, T., and Leinzi, M. A. (2011), Riparian forest structure in a morphologically altered gravel-bed river. Canvegno di medio Termine dell' Associazione Haliana Ingegneria Agraria Belgrate, 22-24 memorian.

Mubi, A. M. (2008) An analysis and mapping of physical land characteristics for the

conservation and management of flora of Gashaka-Gumti National Park, Nigeria

Unpublished Ph.D Thesis in the Department of Geography, Bayero University Kano, Nigeria.

Paul, M. M., Albert, H. T, Judith, A. O, and Kathleen, A. D. (2010), Introduction to the featured collection on riparian ecosystems and buffers, Journal of the American Water Resources Association (JAWRA), 46, 207-210.

Renöfält, B. M., Nilson C. and Jasson R. (2005), Spatial and temporal pattern of species richness in a riparian landscape. Journal of Biogeography, Volume 32, Issue 11, Pages 2025-2037.

Robertson, K. M. (2006), Distribution of tree species along point bars of 10 rivers in southeastern US Coastal plain. Journal of Biogeography, 33(1), 121-132.

Steven, M. W., Gray, L.C. and Dominique, B. (1996), Relationship between landforms geomorphic processes and plant communities on a watershed in northern Chichuahuan desert.

Landscape Ecology, 11(6), 151-362.

Thomson, J. R., Taylor, M. P., Fryirs, K. A., and Brierley, G. J. (2001), A geomorphological framework for river characterization and habitat assessment. Aquatic Conservation: Marine and Freshwater Ecosystem, 11, 373-389.

Warren, A. (2001), Valley-side slopes In: Warren A and French J. R. (eds.) Habitat Conservation: Managing the Physical Environment .John Wiley and Sons New York.

Webb, A. A. and Erskine, W. D. (2003), Distribution, recruitment and geomorphic significance of large woody debris in an alluvial forest stream: Tonghi Creek, Southeast Australia. Geomorphology, 51(1-3), 109-126. 
Table 1: Species types, density and diversity distribution within zones along river Kam channel Location Zone A Zone B Zone $\mathrm{C}$ Zones ABC

Channel Mean altitude (320m)

No. of sample units

46

25

46

117

Sample width (m)

5

9

11

25

Sample area $\left(\mathrm{m}^{2}\right)$

125

225

275

Mean elevation (m)

324

348

330

Slope gradient $\left({ }^{\circ}\right)$

1.3

2.6

3.1

2.8

Soil types

Sandy loam

Silt loam

Grave/Sand

Silt loam

Clayey loam

Sandy loam

Species Mean Density

10

10

23

42

Species Mean Diversity

4

Dominant Species

Brachstigia eurycoma

Diospyros spp

Vitex doniana

3

5

12

Andria enermis

Crossopteryx februfuga Grewia mollis Aunnona Senegatense Uapaka togoensis

Anogeisus leocanpus Vitelaria paraduxa

Parinari excelsa

Pcedio ciria kochyell

Uapaka togoensis Termnalia glaucoscens

Anonna senegalensis 
Table 2: Species density and diversity distribution within river bank morphologic form along Mayo

(River) Kam

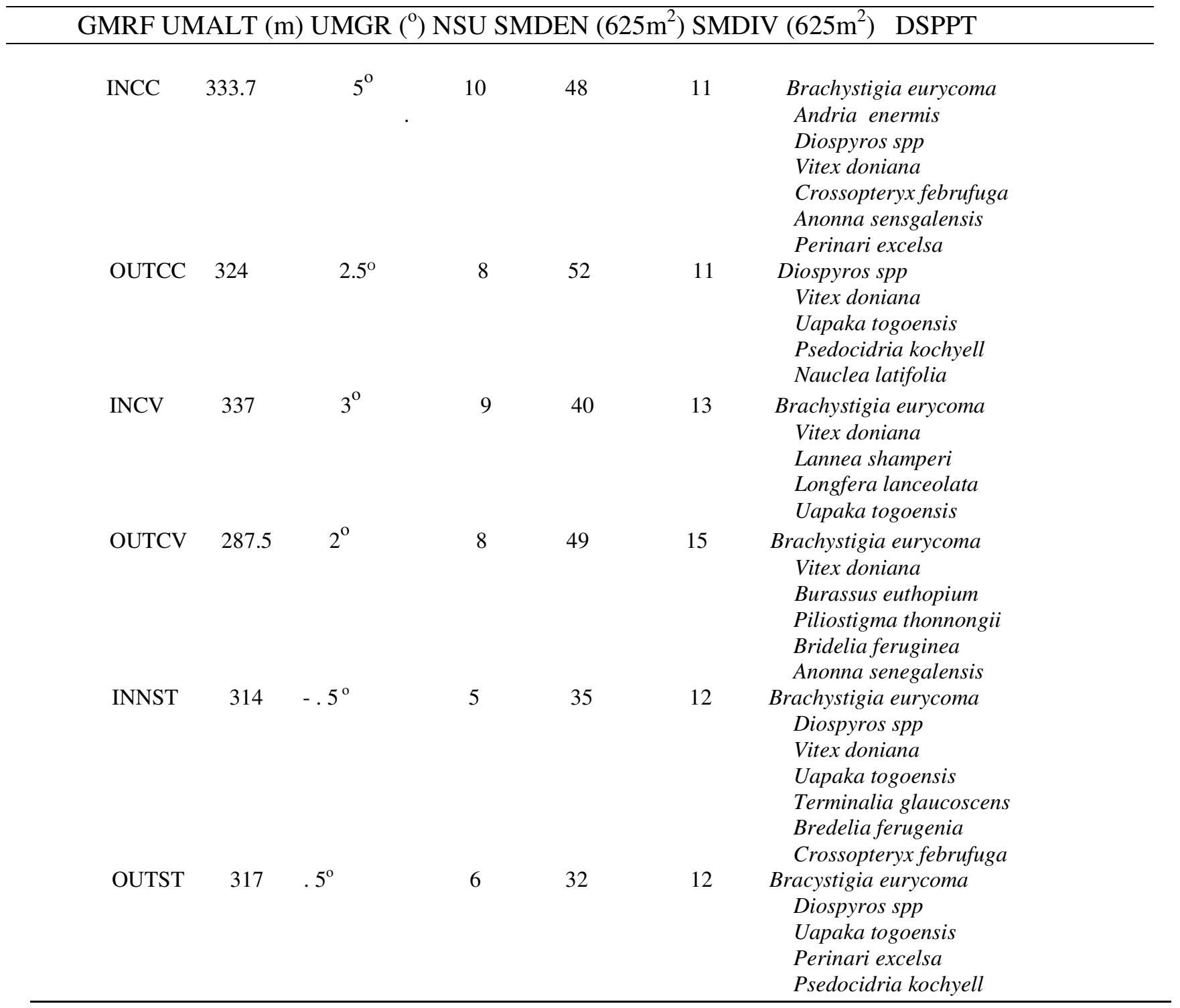

- GMRF- Geormorphic form • UMAL- Unit mean altitude • UMGR- Unit mean gradient NSU- Number of sample units $\bullet$ SMDEN- Species mean density $\bullet$ SMDIV- Species mean diversity• DSPPT- Dominant species types. 


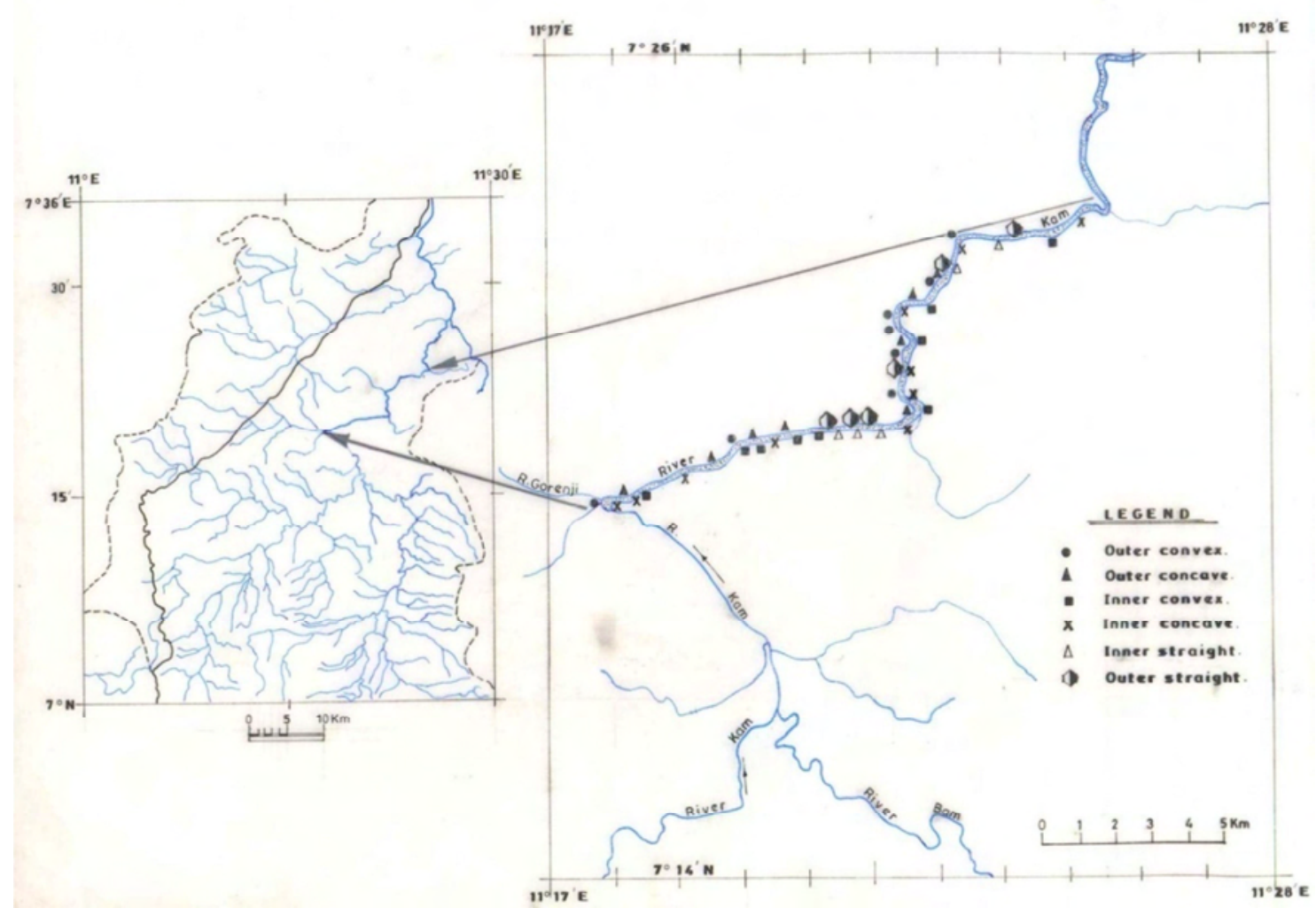

Figure 1: Map of study area

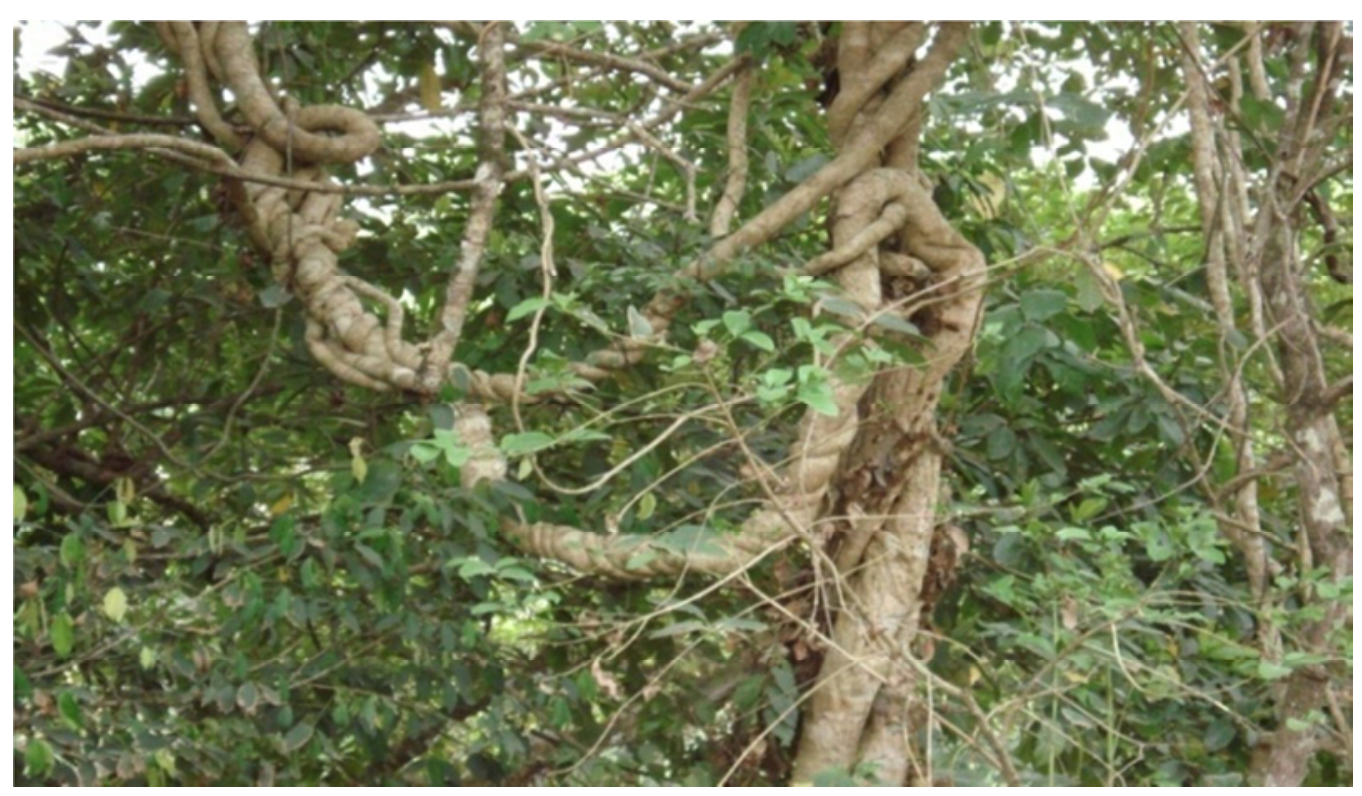

Plate 1: Climbing and tangle vegetation in zone A of the sampled reach along River Ka 


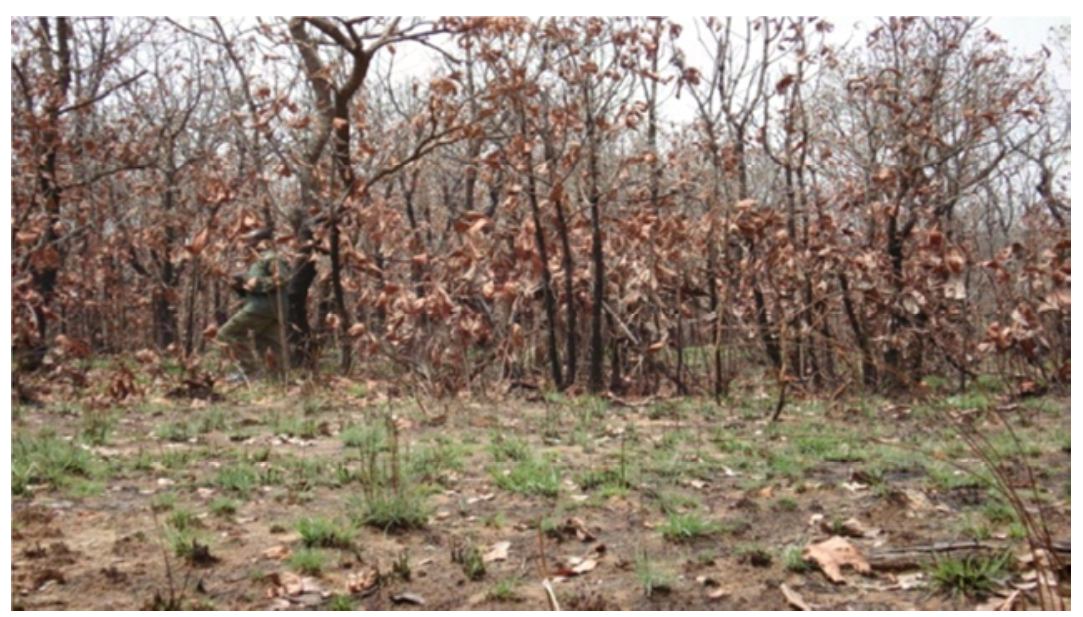

(2a)

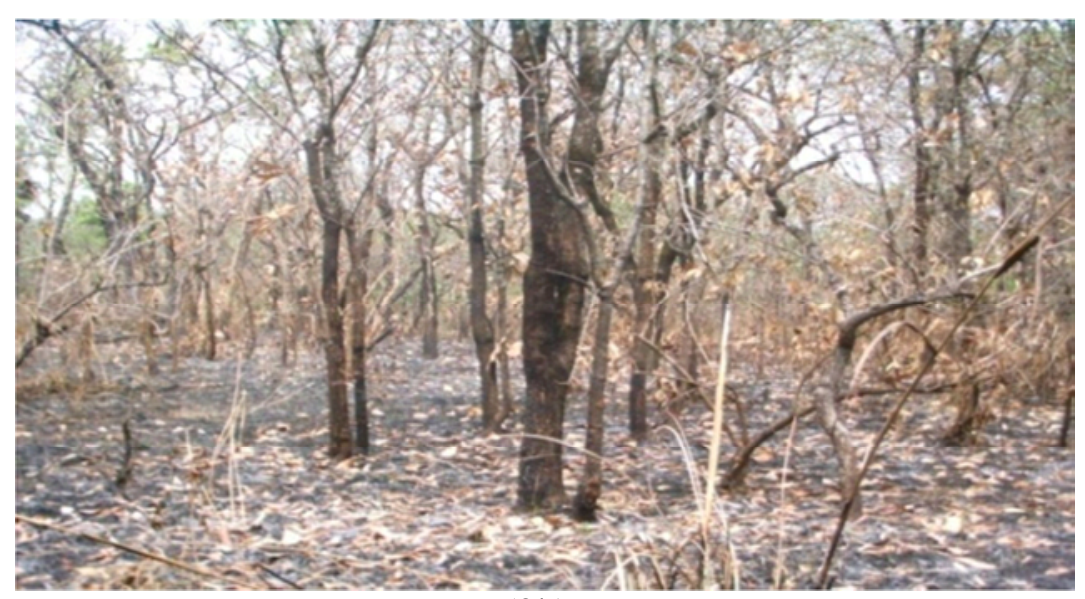

(2b)

Plates $2 \mathrm{a}$ and $\mathrm{b}$ : Burned vegetation exposing bare surface, $2 \mathrm{a}$ depicting zones $\mathrm{B}$ and $\mathrm{C}$ from the river channel and $2 \mathrm{~b}$ some distance from the river channel

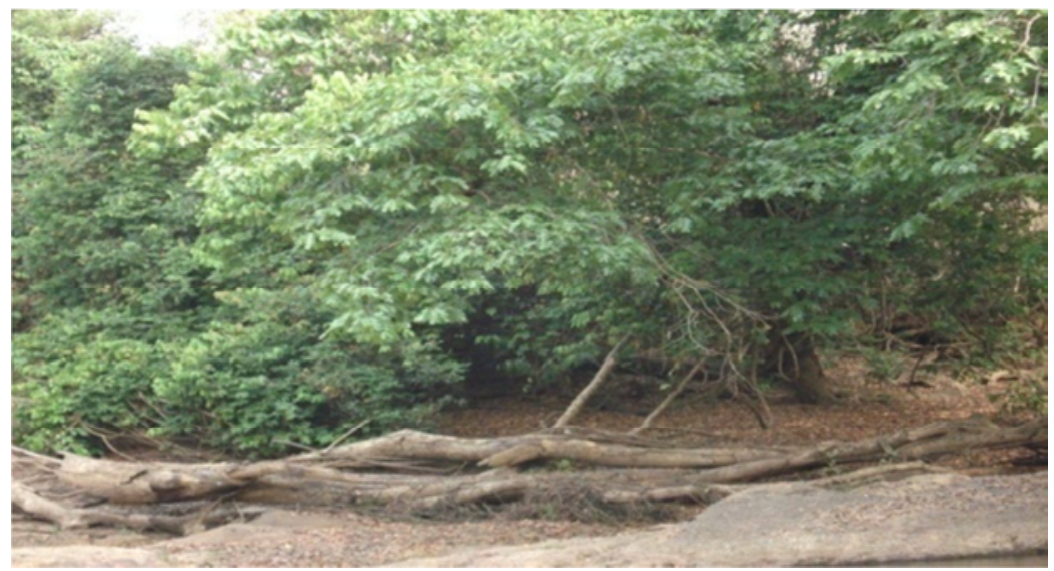

Plate 3: Fallen vegetation from the bank into the river channel River Kam 